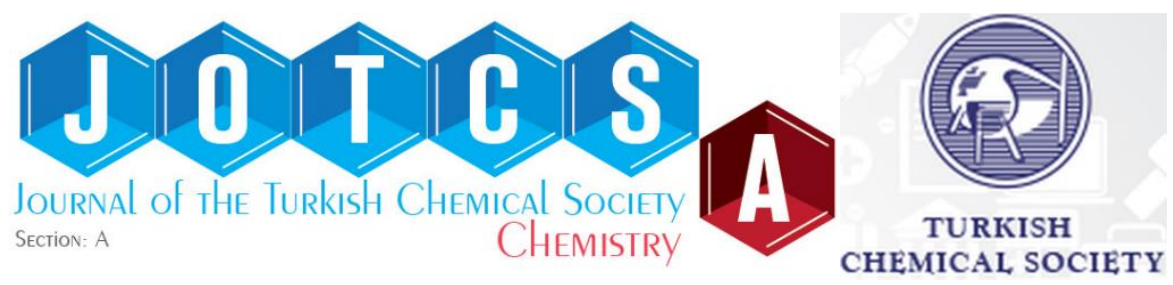

\title{
Novel Metal Complexes of Mixed Piperaquine-Acetaminophen and Piperaquine-Acetylsalicylic acid: Synthesis, Characterization and Antimicrobial Activities
}

\author{
Ayipo Yusuf Oloruntoyin. ${ }^{1 *}$, Obaleye Joshua Ayoola. ${ }^{2}$, Badeggi Umar Muhammad. ${ }^{3}$ \\ 1* Department of Chemical, Geological and Physical Sciences, Kwara State University, Malete, \\ Ilorin, Nigeria. \\ 2 Department of Chemistry, University of Ilorin, Ilorin, Kwara State, Nigeria. \\ ${ }^{3}$ Department of Chemistry, Ibrahim Badamasi Babangida University, Lapai, Niger State, \\ Nigeria.
}

\begin{abstract}
Synthesis of coordination compounds of zinc(II), copper(II), nickel(II), cobalt(II), and iron(II) with mixed piperaquine-acetaminophen and piperaquine-acetylsalicylic acid has been studied. The complexes were characterized via the following: solubility test, melting point determination, conductivity measurement, atomic absorption spectroscopy, UV-Visible spectrophotometry, FTIR spectroscopy and magnetic susceptibility. The complexes were proposed to have a stoichiometry ratio of $1: 1: 1$ between each metal salt and the ligands with tetrahedral and octahedral geometry following the reaction pattern of $M X \cdot y H_{2} \mathrm{O}+\mathrm{L}_{1} \mathrm{~L}_{2 / 3}$ to give $\mathrm{ML}_{1} \mathrm{~L}_{2 / 3} \mathrm{X} . \mathrm{yH}_{2} \mathrm{O}$. Biological activities of the synthesized complexes have been evaluated against Escherichia coli and Staphylococcus aureus.
\end{abstract}

Keywords: Antimalarial activity; analgesic compounds; mixed ligands; spectroscopy; biological activities.

Submitted: October 05 2016. Revised: November 17, 2016. Accepted: November 21, 2016.

Cite this: Ayipo Y, Obaleye J, Badeggi U. Novel Metal Complexes of Mixed PiperaquineAcetaminophen and Piperaquine-Acetylsalicylic acid: Synthesis, Characterization and Antimicrobial Activities. JOTCSA. 2017;4(1):313-26.

DOI: To be assigned.

*Corresponding author. E-mail: ayipochem@yahoo.com. 


\section{INTRODUCTION}

Malaria is one of the major devastating diseases affecting humans since the dawn of history. Over half a billion people are infected with malaria parasite while more than a million die annually from its effect [1]. Children and mostly people with low-income economy are more vulnerable; averagely 3000 children die daily from malaria in Africa [2]. Malaria is caused by an infection of the body by single-cell plasmodia protozoa; though being a very simple organism, it has a complex life cycle with many forms [3]. Since the discovery of the naturally-occurring alkaloids, quinine is an effective therapeutic drug against malaria, numerous antimalarial drugs such as quinacrine, chloroquine, sulfadoxine, etc have been in circulation, until the parasites developed resistance against most of them. Currently, pyrimethamine, sulfonamide, artemisinin, and its derivatives, halofantrine, clindamycin, piperaquine, etc are mostly in use [4]. The parasites are developing resistance against most of the monotherapy antimalarial drugs, making them less effective; thus, the emergence of combination therapy in forms of Artemisinin Combination Therapies (ACTs) e. g. Coartem $^{(R)}$, Artekin ${ }^{(R)}$ etc. Fansidar ${ }^{(R)}$ is another combination therapy containing sulfadoxine and pyrimethamine; which possess a better efficacy against the monotherapy-resistant malarial parasites than their respective single forms [5]. Piperaquine is a derivative of quinine, belonging to the 4-aminoquinoline groups. It was replaced for chloroquine in 1978 in China as a first line monotherapy for malaria and metric tons were dispensed for mass prophylaxis until resistant become too high [6]. Recently, piperaquine had become an object of renewed interest as a partner drug in ACTs. Dihydroartemisinin-piperaquine (Artekin) is one of the most common artemisinin combination for effective, short-course, and affordable malaria therapy with limited side effects and lower risks of recurrence of falciparum parasite [7]. Synriam ${ }^{(R)}$, containing $150 \mathrm{mg}$ arterolane maleate and $750 \mathrm{mg}$ piperaquine phosphate is an oral fixed-dose combination antimalarial for Plasmodium falciparum and Plasmodium vivax in children and adults [8]. These and many more justify the aim of this research effort; to develop an antimalarial-analgesic fixed combination therapy against the strains of monotherapy-resistant plasmodium parasites especially those associated with fever and severe pain symptoms. Thus, the synthesis of piperaquine-acetaminophen and piperaquineacetylsalicylic acid becomes a worth-taking approach of antimalarial research.

\section{Materials}

All chemicals used are of analytical and reagent grades, used as commercially obtained without further purification. Piperaquine phosphate (antimalarial ligand) was obtained from Zhuhai Runde Pharmaceutical Ltd., Guangzhou province, China, while acetaminophen and acetylsalicylic acid (analgesic ligands) were obtained from Rajrab Pharmeceutical Ltd., Ilorin. Transition metal salts and other solvents were obtained from Aldrich, BDH England. 


\section{EXPERIMENTAL}

\section{Synthesis of mixed piperaquine-acetaminophen metal complexes}

The complexes were synthesized following some reported procedure with slight analytical modifications [5], [9], [10]. An aqueous-ethanolic solution of each metal salt (0.01 mol of each) was prepared in a round-bottomed flask. $5.355 \mathrm{~g}(0.01 \mathrm{~mol})$ of piperaquine phosphate was mixed with $1.512 \mathrm{~g}(0.01 \mathrm{~mol})$ of acetaminophen in a beaker. The mole ratio of the mixture of piperaquine phosphate, metal salt and acetaminophen was 1:1:1. The mixed ligands were dissolved in $20 \mathrm{~mL}$ of $5 \%$ lactic acid due to poor solubility of piperaquine in water even when fully ionized [19] and added to each solution of the corresponding metal salt dissolved previously in $10 \mathrm{~mL}$ of ethanol in a round-bottomed flask fitted with a condenser. The $\mathrm{pH}$ of the mixture was maintained by the addition of $10 \%$ methanolic ammonical solution. The mixture was refluxed at $70^{\circ} \mathrm{C}$ for 4 hours and kept thereafter in a refrigerator for 30 minutes for the metal chelate to crystallize. The crystals were then filtered and washed with dilute lactic acid and then distilled water to remove unreacted ligands and metals. The complexes were then dried in a desiccator for 3 days. The same procedure was applied for all metal salts.

\section{Synthesis of mixed piperaquine-acetylsalicylic acid metal complexes}

The procedure as reported above [5], [9], [10] was followed with some slight modifications such as change in analgesic ligands and the reflux time.

\section{Determination of some properties of the complexes}

Physical observations of the colors of the synthesized complexes were made and compared with those of the free ligands and the metal salts. The percentage yields were calculated and approximated to the nearest whole number. The melting points and conductivities were measured using Gallenkamp melting point apparatus and WTW conductimeter bridge, respectively and the values were recorded to a single whole number without range. Purity of the complexes was confirmed as a single spot on a thin layer chromatography (TLC) plate. Magnetic susceptibilities were deduced from the magnetic moment obtained on Sherwood Scientific Magnetic Susceptibility Balance. Infrared spectra of the synthesized complexes and the free ligands were recorded in $\mathrm{KBr}$ pellets using a Shimadzu FTIR-8400s (IR solution model) in the range of $4000-500 \mathrm{~cm}^{-1}$. As a UV-Visible spectrometer, Beckman Coulter DU-730 was used to run the electronic transition of the complexes and the free ligands. Atomic Absorption Spectroscopy (AAS) analysis was used to determine the metal content of the complexes (which confirms evidence of coordination) was carried out using the Alpha 4 AAS PM 8251 single pen recorder. 
Ayipo, Obaleye and Badeggi, JOTCSA. 2017; 4(1): 313-326.

\section{Antimicrobial Screening}

Antimicrobial activities of the free ligands and the complexes were deduced from their inhibitory potentials against Escherichia coli and Staphylococcus aureus on the basis of zones formed around their wells [5], [9].

\section{Results}

Table 1: Reaction pattern between ligands and metal salts to form complexes

$$
\begin{aligned}
& M X . y H_{2} \mathrm{O}+\mathrm{L}_{1} \mathrm{~L}_{2} \rightarrow\left[\mathrm{ML}_{1} \mathrm{~L}_{2}\right] \mathrm{X} . \mathrm{yH}_{2} \mathrm{O} \\
& M X . y H_{2} \mathrm{O}+\mathrm{L}_{1} \mathrm{~L}_{3} \rightarrow\left[\mathrm{ML}_{1} \mathrm{~L}_{3}\right] \mathrm{X} . \mathrm{yH}_{2} \mathrm{O} \\
& \text { Where } \mathrm{M}=\mathrm{Cu}(\mathrm{II}) ; \mathrm{Co}(\mathrm{II}) ; \mathrm{Zn}(\mathrm{II}) \text { and } \mathrm{Fe}(\mathrm{II}) \\
& \mathrm{X}=\mathrm{Cl}_{2}, \mathrm{SO}_{4} \text { and } \mathrm{OAC}_{2} \\
& \mathrm{~L}_{1}, \mathrm{~L}_{2} \text { and } \mathrm{L}_{3}=\text { Piperaquine, Acetylsalicylic acid, Acetaminophen } \\
& \text { Ligands + Metal salt Proposed chemical formula } \\
& \mathrm{PQ}+\mathrm{PC}+\mathrm{CuCl}_{2} \quad \mathrm{Cu}(\mathrm{PQ})(\mathrm{PC}) \mathrm{Cl}_{2} \\
& \mathrm{PQ}+\mathrm{PC}+\mathrm{Co}(\mathrm{OAC})_{2} \quad \mathrm{Co}(\mathrm{PQ})(\mathrm{PC})(\mathrm{OAC})_{2} \\
& \mathrm{PQ}+\mathrm{PC}+\mathrm{ZnSO}_{4} \quad \mathrm{Zn}(\mathrm{PQ})(\mathrm{PC}) \mathrm{SO}_{4} \\
& \mathrm{PQ}+\mathrm{PC}+\mathrm{FeCl}_{2} \quad \mathrm{Fe}(\mathrm{PQ})(\mathrm{PC}) \mathrm{Cl}_{2} \\
& \mathrm{PQ}+\mathrm{AS}+\mathrm{Cu}(\mathrm{OAC})_{2} \quad \mathrm{Cu}(\mathrm{PQ})(\mathrm{AS})(\mathrm{OAC})_{2} \\
& \mathrm{PQ}+\mathrm{AS}+\mathrm{ZnSO}_{4} \quad \mathrm{Zn}(\mathrm{PQ})(\mathrm{AS}) \mathrm{SO}_{4}
\end{aligned}
$$


Ayipo, Obaleye and Badeggi, JOTCSA. 2017; 4(1): 313-326.

\section{Proposed Complex Structures}

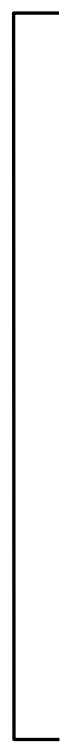

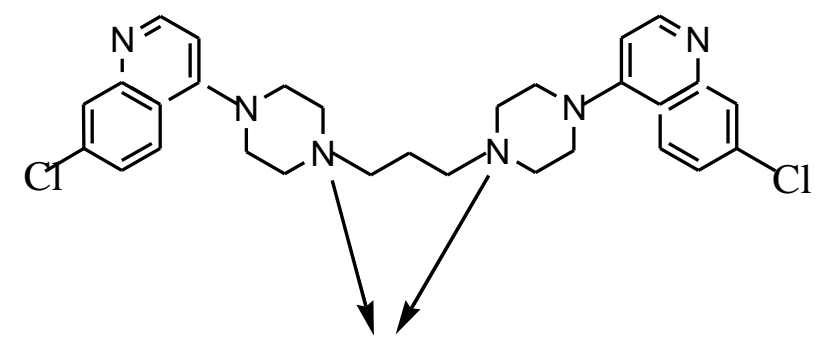

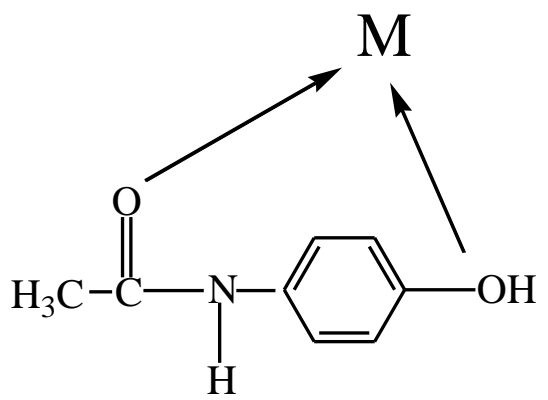

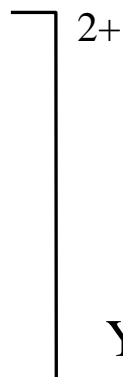

Y. $\mathrm{xH}_{2} \mathrm{O}$

where $\mathrm{Y}=\mathrm{Cl}_{2}, \mathrm{SO}_{4}$ or $\left(\mathrm{CH}_{3} \mathrm{COO}\right)_{2}$

Figure 1: $M-(P Q)(P C):$ Where $M=C u(I I), Z n(I I), C o(I I)$, and $\mathrm{Fe}(\mathrm{II})$ ions.
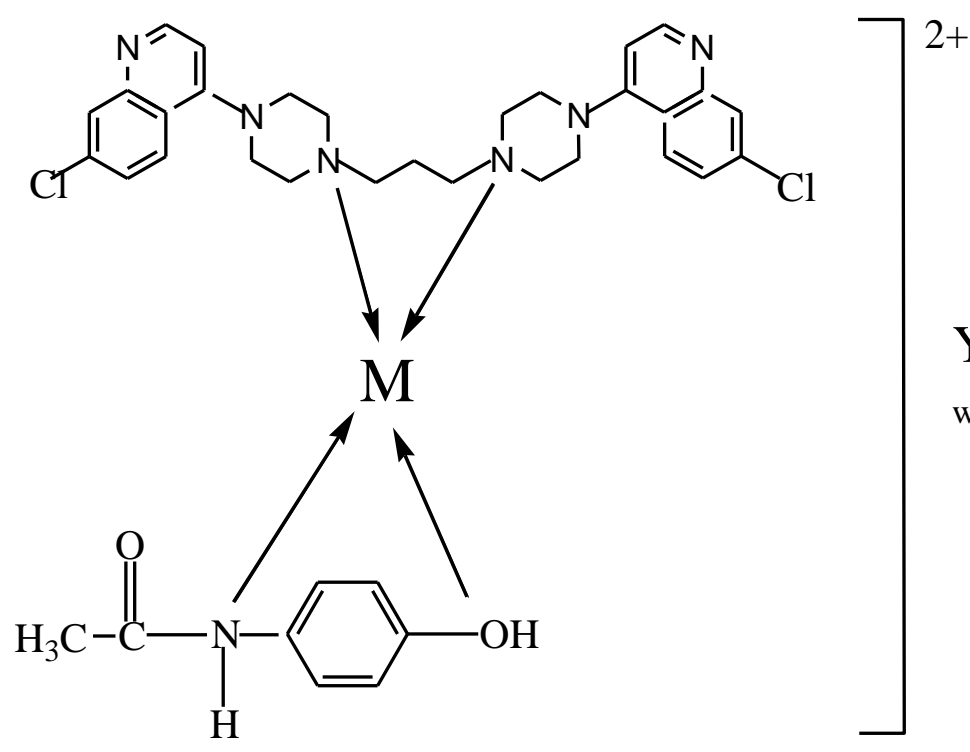

Y. $\mathrm{xH}_{2} \mathrm{O}$

where $\mathrm{Y}=\mathrm{Cl}_{2}, \mathrm{SO}_{4}$ or $\left(\mathrm{CH}_{3} \mathrm{COO}\right)_{2}$

Figure 2: $M-(P Q)(P C):$ Where $M=C u(I I), Z n(I I), C o(I I)$, and $\mathrm{Fe}(\mathrm{II})$ ions. 

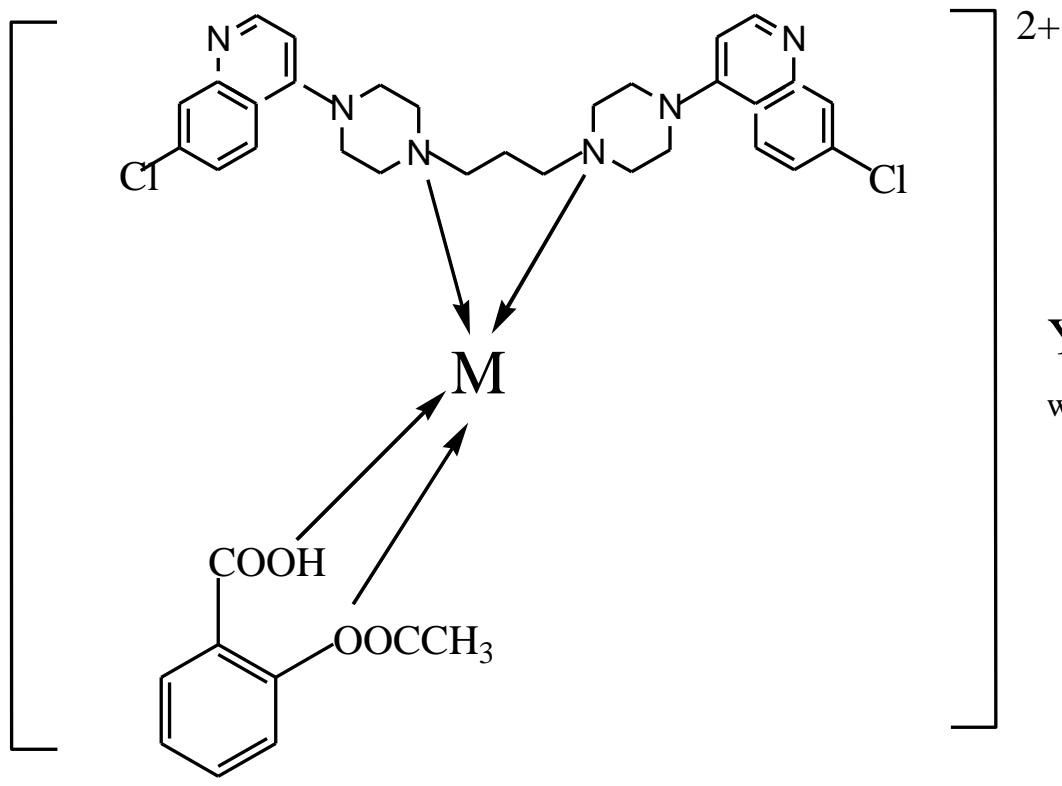

Y. $\mathrm{xH}_{2} \mathrm{O}$

where $\mathrm{Y}=\mathrm{Cl}_{2}, \mathrm{SO}_{4}$ or $\left(\mathrm{CH}_{3} \mathrm{COO}\right)_{2}$

Figure 3: $M-(P Q)(A S)$ : Where $M=C u(I I), Z n(I I), C o(I I)$, and $\mathrm{Fe}(\mathrm{II})$ ions.

Table 2: Some physical properties of the ligands and the complexes.

\begin{tabular}{|c|c|c|c|c|c|}
\hline Sample & Color & Yield (\%) & M. P. $\left({ }^{\circ} \mathrm{C}\right)$ & $\begin{array}{l}\text { Metal } \\
\text { Content (\%) } \\
\text { Experimental } \\
\text { (Calculated) }\end{array}$ & $\begin{array}{l}\text { Conductivity } \\
\left(\Omega^{-1} \mathrm{~cm}^{-1}\right)\end{array}$ \\
\hline$P Q$ & White-yellow & - & 249 & - & $6.2 \times 10^{-6}$ \\
\hline AS & White & - & 138 & - & $3.3 \times 10^{-4}$ \\
\hline PC & White & - & 169 & - & $4.1 \times 10^{-4}$ \\
\hline $\mathrm{Cu}(\mathrm{PQ})(\mathrm{PC}) \mathrm{Cl}_{2}$ & Blue & 36 & 155 & $8.20(7.93)$ & $8.3 \times 10^{-5}$ \\
\hline $\mathrm{Co}(\mathrm{PQ})(\mathrm{PC})(\mathrm{OAC})_{2}$ & Faded pink & 68 & 195 & $7.10(6.85)$ & $8.2 \times 10^{-5}$ \\
\hline $\mathrm{Zn}(\mathrm{PQ})(\mathrm{PC}) \mathrm{SO}_{4}$ & White & 76 & 219 & $12.30(14.26)$ & $6.1 \times 10^{-5}$ \\
\hline $\mathrm{Fe}(\mathrm{PQ})(\mathrm{PC}) \mathrm{Cl}_{2}$ & Grey & 25 & 205 & $6.60(6.58)$ & $6.5 \times 10^{-5}$ \\
\hline $\mathrm{Cu}(\mathrm{PQ})(\mathrm{AS})(\mathrm{OAC})_{2}$ & Blue & 28 & 206 & $8.10(7.57)$ & $3.5 \times 10^{-5}$ \\
\hline $\mathrm{Zn}(\mathrm{PQ})(\mathrm{AS}) \mathrm{SO}_{4}$ & White & 20 & 170 & $7.60(7.52)$ & $3.2 \times 10^{-6}$ \\
\hline
\end{tabular}


Ayipo, Obaleye and Badeggi, JOTCSA. 2017; 4(1): 313-326.

RESEARCH ARTICLE

Table 3: Solubility of the ligands and the complexes in some selected solvents.

\begin{tabular}{|c|c|c|c|c|c|c|c|}
\hline Sample & $\begin{array}{l}\mathrm{H}_{2} \mathrm{O} \\
\text { (r.t.p) }\end{array}$ & $\begin{array}{l}\mathrm{H}_{2} \mathrm{O} \\
(\mathbf{1 0 0} \\
\left.{ }^{\circ} \mathrm{C}\right)\end{array}$ & Ethanol & $\begin{array}{l}\text { Dil. } \\
\text { Lactic } \\
\text { Acid }\end{array}$ & Acetone & DMSO & Methanol \\
\hline $\mathrm{PQ}$ & SS & $\mathrm{S}$ & IS & $\mathrm{S}$ & IS & IS & IS \\
\hline AS & SS & $\mathrm{S}$ & SS & SS & IS & $\mathrm{S}$ & S \\
\hline PC & IS & IS & $\mathrm{S}$ & SS & SS & S & S \\
\hline $\mathrm{Cu}(\mathrm{PQ})(\mathrm{PC}) \mathrm{Cl}_{2}$ & IS & $\mathrm{s}$ & IS & $\mathrm{s}$ & SS & SS & SS \\
\hline $\mathrm{Co}(\mathrm{PQ})(\mathrm{PC})(\mathrm{OAC})_{2}$ & IS & SS & SS & $\mathrm{S}$ & IS & S & SS \\
\hline $\mathrm{Zn}(\mathrm{PQ})(\mathrm{PC}) \mathrm{SO}_{4}$ & IS & SS & IS & $\mathrm{s}$ & IS & S & IS \\
\hline $\mathrm{Fe}(\mathrm{PQ})(\mathrm{PC}) \mathrm{Cl}_{2}$ & SS & SS & IS & IS & IS & S & SS \\
\hline $\mathrm{Cu}(\mathrm{PQ})(\mathrm{AS})(\mathrm{OAc})_{2}$ & SS & $\mathrm{S}$ & IS & $\mathrm{S}$ & IS & S & SS \\
\hline $\mathrm{Zn}(\mathrm{PQ})(\mathrm{AS}) \mathrm{SO}_{4}$ & SS & $\mathrm{S}$ & IS & $\mathrm{s}$ & IS & s & IS \\
\hline
\end{tabular}

$\mathrm{S}=$ Soluble; $\mathrm{SS}=$ Sparingly soluble; IS = Insoluble.

Table 4: Magnetic moments, electronic transition and Some FTIR spectra assignment

\begin{tabular}{|c|c|c|c|c|c|}
\hline Sample & $\mu_{\text {eff }}(B M)$ & Water $\lambda_{\max }(\mathrm{nm})$ & $\mathrm{V}(\mathrm{N}-\mathrm{H}) \mathrm{cm}^{-1}$ & $\mathrm{~V}(\mathrm{O}-\mathrm{H}) \mathrm{cm}^{-1}$ & $\begin{array}{l}\mathrm{V}(\mathrm{C}=0) \\
\mathrm{cm}^{-1}\end{array}$ \\
\hline $\mathrm{PQ}$ & - & 379 & $3433.41 \mathrm{~m}, \mathrm{~b}$ & - & - \\
\hline AS & - & 282 & - & $2999.41 \mathrm{~m}, \mathrm{~b}$ & $1691.63 \mathrm{~s}, \mathrm{~S}$ \\
\hline PC & - & 306 & $3327.32 \mathrm{~s}, \mathrm{~b}$ & $3161.43 \mathrm{~m}$ & $1654.98 \mathrm{~s}$ \\
\hline $\mathrm{Cu}(\mathrm{PQ})(\mathrm{PC}) \mathrm{Cl}_{2}$ & 2.23 & 392 & $3327.32 \mathrm{~s}, \mathrm{~b}$ & $3163.36 \mathrm{~b}$ & $1654.98 \mathrm{~s}, \mathrm{~S}$ \\
\hline $\mathrm{Co}(\mathrm{PQ})(\mathrm{PC})(\mathrm{OAC})_{2}$ & 4.78 & 389 & $3649.14 \mathrm{w}$ & $3055.35 \mathrm{~m}$ & $1606.76 \mathrm{~m}$ \\
\hline $\mathrm{Zn}(\mathrm{PQ})(\mathrm{PC}) \mathrm{SO}_{4}$ & 1.89 & 392 & $3541.42 \mathrm{~s}, \mathrm{~b}$ & - & $1633.76 \mathrm{~m}, \mathrm{~b}$ \\
\hline $\mathrm{Fe}(\mathrm{PQ})(\mathrm{PC}) \mathrm{Cl}_{2}$ & 5.10 & 250 & $3381.33 \mathrm{~s}, \mathrm{~b}$ & - & $1624.12 \mathrm{~m}$ \\
\hline $\mathrm{Cu}(\mathrm{PQ})(\mathrm{AS})(\mathrm{OAC})_{2}$ & 2.30 & 390 & $3441.12 \mathrm{~m}, \mathrm{~b}$ & $3234.73 \mathrm{w}$ & $1622.19 \mathrm{~m}$ \\
\hline $\mathrm{Zn}(\mathrm{PQ})(\mathrm{AS}) \mathrm{SO}_{4}$ & 1.76 & 393 & $3358.18 \mathrm{~s}, \mathrm{~b}$ & $3066.92 \mathrm{~m}, \mathrm{~b}$ & - \\
\hline
\end{tabular}

$\mathrm{m}=$ medium $; \mathrm{b}=$ broad $; \mathrm{s}=$ strong; $\mathrm{w}=$ weak $\mathrm{S}=$ sharp 
Ayipo, Obaleye and Badeggi, JOTCSA. 2017; 4(1): 313-326.

Table 5: Biological activities of the ligands and the complexes

\begin{tabular}{llll}
\hline Sample & $\begin{array}{l}\text { Concentration } \\
(\%)\end{array}$ & $\begin{array}{l}\text { Zone of Inhibition in } \\
\text { Staphylococcus aureus } \\
(\mathbf{m m})\end{array}$ & $\begin{array}{l}\text { Zone of Inhibition } \\
\text { in Escherichia coli } \\
(\mathbf{m m})\end{array}$ \\
\hline $\mathrm{PQ}$ & 1.0 & 3.55 & 5.60 \\
$\mathrm{AS}$ & 1.0 & 2.50 & 4.00 \\
$\mathrm{PC}$ & 1.0 & 2.00 & 3.50 \\
$\mathrm{Cu}(\mathrm{PQ})(\mathrm{PC}) \mathrm{Cl}_{2}$ & 1.0 & 5.00 & 5.00 \\
$\mathrm{Co}(\mathrm{PQ})(\mathrm{PC})(\mathrm{OAc})_{2}$ & 1.0 & 4.20 & 5.80 \\
$\mathrm{Zn}(\mathrm{PQ})(\mathrm{PC}) \mathrm{SO}_{4}$ & 1.0 & 4.80 & 5.00 \\
$\mathrm{Fe}(\mathrm{PQ})(\mathrm{PC}) \mathrm{Cl}_{2}$ & 1.0 & 5.20 & 5.80 \\
$\mathrm{Cu}(\mathrm{PQ})(\mathrm{AS})(\mathrm{OAc})_{2}$ & 1.0 & 3.25 & 5.00 \\
$\mathrm{Zn}(\mathrm{PQ})(\mathrm{AS}) \mathrm{SO}_{4}$ & 1.0 & 4.60 & 5.40 \\
\hline
\end{tabular}

\section{DISCUSSIONS}

The complexes (Table 2) show different colors due to the presence of transition metal charge transfer to the ligands transition compared to the free ligands [11], [12]. The percentage yield of the complexes varied due to different factors such as the variation in electronic configuration of the metal ion in d-orbital, size of the ion, nature of the electron donation agent (donating atom on the ligand), functional groups of the ligands as Lewis bases and the reaction conditions [12]. The highest percentage yield was observed in $\mathrm{Zn}(\mathrm{PQ})(\mathrm{PC}) \mathrm{SO}_{4}$ while the lowest was found in $\mathrm{Zn}(\mathrm{PQ})(\mathrm{AS}) \mathrm{SO}_{4}$. The synthesized complexes were photo- and thermo-stable crystals with varied melting points due to the octahedral and tetrahedral geometry (Figures 1-3) of the transition metal complexes. The melting points of free piperaquine (PQ) ligand are higher than those of the complexes [9]. The percentage metal content as found experimentally is in good agreement with the calculated values as the data in Table 2 reveal. Molar conductivities of the metal complexes in water show non-electrolytic behavior of the free ligands and the complexes in the solvent.

The results of solubility tests (Table 3 ) show the solubility nature of the free ligands and the complexes in distilled water (at room temperature and at $100{ }^{\circ} \mathrm{C}$ ), ethanol, dilute lactic acid, acetone, dimethylsulfoxide (DMSO), and methanol. Most of the complexes dissolved completely 
Ayipo, Obaleye and Badeggi, JOTCSA. 2017; 4(1): 313-326.

in hot water and dilute lactic acid, some dissolved sparingly in DMSO and methanol, while others are practically insoluble in ethanol and acetone. None of the complexes is soluble in water, $\mathrm{Fe}(\mathrm{PQ})(\mathrm{PC}) \mathrm{Cl}_{2}, \mathrm{Cu}(\mathrm{PQ})(\mathrm{AS})(\mathrm{OAC})_{2}$ and $\mathrm{Zn}(\mathrm{PQ})(\mathrm{AS}) \mathrm{SO}_{4}$ are sparingly soluble while $\mathrm{Cu}(\mathrm{PQ})(\mathrm{PC})$, $\mathrm{Co}(\mathrm{PQ})(\mathrm{PC})(\mathrm{OAc})_{2}$ and $\mathrm{Zn}(\mathrm{PQ})(\mathrm{PC}) \mathrm{SO}_{4}$ are insoluble. In ethanol, none of them is soluble, $\mathrm{Co}(\mathrm{PQ})(\mathrm{PC})(\mathrm{OAc})_{2}$ is sparingly soluble while others are insoluble. In dilute lactic acid, all the complexes are dissolved well except $\mathrm{Fe}(\mathrm{PQ})(\mathrm{PC}) \mathrm{Cl}_{2}$ which is sparingly soluble. None is fully dissolved in acetone; only $\mathrm{Cu}(\mathrm{PQ})(\mathrm{PC}) \mathrm{Cl}_{2}$ is sparingly soluble, others are practically insoluble. In DMSO, only $\mathrm{Cu}(\mathrm{PQ})(\mathrm{PC}) \mathrm{Cl}_{2}$ is sparingly soluble, others dissolve well and none is insoluble. None of the complexes fully dissolves in methanol, $\mathrm{Zn}(\mathrm{PQ})(\mathrm{PC}) \mathrm{SO}_{4}$ and $\mathrm{Zn}(\mathrm{PQ})(\mathrm{AS}) \mathrm{SO}_{4}$ are insoluble while others are sparingly soluble.

The results of the magnetic moment (Table 4) show that $\mathrm{Co}$ (II) and $\mathrm{Zn}$ (II) complexes conform in a stoichiometric manner with tetrahedral geometry while $\mathrm{Cu}$ (II) and $\mathrm{Fe}$ (II) are proposed within the range of octahedral configuration. It also reveals that some of the $\mathrm{Zn}(\mathrm{PQ})(\mathrm{PC}) \mathrm{SO}_{4}$ and $\mathrm{Zn}(\mathrm{PQ})(\mathrm{AS}) \mathrm{SO}_{4}$ complexes are diamagnetic due to unavailable of unpaired electrons on d-orbital of the $\mathrm{Zn}^{2+}$ ion, $\mathrm{Fe}(\mathrm{PQ})(\mathrm{PC}) \mathrm{Cl}_{2}$ are ferromagnetic, while $\mathrm{Cu}(\mathrm{PQ})(\mathrm{PC}), \mathrm{Co}(\mathrm{PQ})(\mathrm{PC})(\mathrm{OAc})_{2}$ and $\mathrm{Cu}(\mathrm{PQ})(\mathrm{AS})(\mathrm{OAc})_{2}$ are paramagnetic due to the presence of unpaired electron on $\mathrm{d}$-orbital of the $\mathrm{Cu}^{2+}$ and $\mathrm{Co}^{2+}$ ions. The analytical data obtained provides a supportive evidence for the stoichiometric ratio of $1: 1: 1$ between the metal ion and the ligands [14], [15]. The free piperaquine, acetylsalicylic acid and acetaminophen show a $\lambda_{\max }$ of $379 \mathrm{~nm}, 282 \mathrm{~nm}$ and $306 \mathrm{~nm}$ respectively on UV-Visible spectroscopy. The shifting of these bands to a higher wavelength in $\mathrm{Cu}(\mathrm{PQ})(\mathrm{PC}) \mathrm{Cl}_{2}, \mathrm{Co}(\mathrm{PQ})(\mathrm{PC})(\mathrm{OAC}), \mathrm{Zn}(\mathrm{PQ})(\mathrm{PC}) \mathrm{SO}_{4}, \mathrm{Cu}(\mathrm{PQ})(\mathrm{AS})(\mathrm{OAC})_{2}$ and $\mathrm{Zn}(\mathrm{PQ})(\mathrm{PC}) \mathrm{SO}_{4}$ confirmed the effective coordination and the formation of complexes between the metal ions and the ligands [9]. Although the $\lambda_{\max }$ values for $\mathrm{Cu}(\mathrm{PQ})(\mathrm{PC}) \mathrm{Cl}_{2}, \mathrm{Cu}(\mathrm{PQ})(\mathrm{AS})(\mathrm{OAC})_{2}$ and $\mathrm{Zn}(\mathrm{PQ})(\mathrm{PC}) \mathrm{SO}_{4}$ did not really cross the border from UV to Visible region but could be approximated to the visible region and having slight evidences for $d$ - $d$ electron transition - hence the coloration [11]. The selective infrared spectral assignment of free ligands and the complexes have been carried out based on similar compounds [14, 16, 17]. The medium broad absorption band of $3433.41 \mathrm{~cm}^{-1}$ found in the spectrum of free piperaquine and the strong broad band of $3327.32 \mathrm{~cm}^{-1}$ in free acetaminophen due to $\mathrm{N}-\mathrm{H}$ stretch have undergone a hyperchromic shifts to $3649.44 \mathrm{~cm}^{-1}$ and $3541.42 \mathrm{~cm}^{-1}$ in $\mathrm{Co}(\mathrm{PQ})(\mathrm{PC})(\mathrm{OAc})_{2}$ and $\mathrm{Zn}(\mathrm{PQ})(\mathrm{PC}) \mathrm{SO}_{4}$ respectively. The bands for $\mathrm{N}-\mathrm{H}$ stretch in free piperaquine and acetaminophen have also undergone a hypsochromic shifts to $3381.33 \mathrm{~cm}^{-1}, 3441.12 \mathrm{~cm}^{-1}$ and $3358.18 \mathrm{~cm}^{-1}$ in $\mathrm{Fe}(\mathrm{PQ})(\mathrm{PC}) \mathrm{Cl}_{2}$, $\mathrm{Cu}(\mathrm{PQ})(\mathrm{AS})(\mathrm{OAC})_{2}$ and $\mathrm{Zn}(\mathrm{PQ})(\mathrm{AS}) \mathrm{SO}_{4}$ respectively. Infrared spectra which can also probe coordination: The shifting of these $\mathrm{N}-\mathrm{H}$ bands provides evidence of complex formation which is supported by the disappearance of broad $2999.41 \mathrm{~cm}^{-1}$ and $3161.43 \mathrm{~cm}^{-1}$ in free acetylsalicylic acid and acetaminophen spectra assigned to $\mathrm{O}-\mathrm{H}$ in $\mathrm{Zn}(\mathrm{PQ})(\mathrm{PC}) \mathrm{SO}_{4}$ and $\mathrm{Fe}(\mathrm{PQ})(\mathrm{PC}) \mathrm{Cl}_{2}$. The strong absorption bands of $1691.63 \mathrm{~cm}^{-1}$ and $1654.98 \mathrm{~cm}^{-1}$ found in acetylsalicylic acid and acetaminophen respectively have disappeared in $\mathrm{Zn}(\mathrm{PQ})(\mathrm{AS}) \mathrm{SO}_{4}$ and undergo various shifts in other complexes. The variation in the frequencies of the bands of the free ligands compared to 
Ayipo, Obaleye and Badeggi, JOTCSA. 2017; 4(1): 313-326.

those of the complexes denotes the change in vibrational pattern of the ligands upon coordination to metal ions (see Figures 1, 2, and 3).

The presence of some anions such as $\mathrm{Cl}^{-}, \mathrm{SO}_{4}{ }^{2-}$ and $\mathrm{CH}_{3} \mathrm{COO}^{-}$are confirmed by the reaction of the solutions of the metal complexes with aqueous $\mathrm{AgNO}_{3}$, aqueous $\mathrm{BaCl}_{2}$ and neutral $\mathrm{FeCl}_{3}$ [18]. The complexes containing $\mathrm{Cl}^{-}$and $\mathrm{SO}_{4}{ }^{2-}$ ions produce insoluble white precipitates on testing with aqueous $\mathrm{AgNO}_{3}$ and aqueous $\mathrm{BaCl}_{2}$. Those containing $\mathrm{CH}_{3} \mathrm{COO}^{-}$produce red color with $\mathrm{FeCl}_{3}$ solution [18]. The formation of single spots on each TLC chromatography plate confirmed the purity of the complexes.

The proposed reaction pathways and chemical formulas as given in Table 4 above are derived from the cumulative characterization results.

Table 5 presents the results of the biological activities as antimicrobial tests of the free ligands and the complexes against a gram-positive Staphylococcus aureus and Escherichia coli. The inhibition growth effects of the complexes against these bacteria strains show significant differences in metal complex sensitivities as compared to the free ligands [9]. From the results, only $\mathrm{Cu}(\mathrm{PQ})(\mathrm{AS})(\mathrm{OAC})_{2}$ have a lower inhibitory effect against Staphylococcus aureus, other complexes have higher effects compared to the free parent drugs. Against Escherichia coli, piperaquine was experimentally found to possess a higher inhibitory effect than the complexes while the effects of the free acetylsalicylic acid and acetaminophen are lower compared to the complexes. These provide supportive evidences that the metal complexes of mixed piperaquineacetylsalicylic acid and piperaquine-acetaminophen have greater medicinal therapeutic potential against microorganism activities than their parent drugs.

\section{CONCLUSION}

The complexes were synthesized with the ligands (piperaquine, acetylsalicylic acid and acetaminophen) coordinating through $\mathrm{N}-\mathrm{H}, \mathrm{O}-\mathrm{H}$ and $\mathrm{C}=\mathrm{O}$ to the metal ions in the stoichiometric ratio of $1: 1: 1$ to form both tetrahedral and octahedral complexes. Although some reactions yield low complexes while some are impressive, but solubility behaviors to the tested solvents, the melting point and the magnetic susceptibility of the complexes show distinct results from their parent ligands. The metal-ligand coordination is probed with UV-Vis and FTIR spectroscopy. The synthesized complexes were found to possess better physical and antimicrobial properties when compared to their free ligands. Thus, the complexes show a better therapeutic potential against some target bacteria compared to the free antimalarial piperaquine and free analgesic acetylsalicylic acid and acetaminophen and could also be suggested against malaria strains. This conclusion is also supported by the previous relevant research $[5,9,10,14,16]$. However, further characterization and in vitro and in vivo assessment of the complexes to confirm their therapeutic actions against plasmodium strains are needed. 


\section{ACKNOWLEDGEMENT}

The authors wish to appreciate the Director, the Concord School, Ibadan and the Head of Chemistry Department, University of Ilorin, Ilorin, for their support in providing full access to laboratory work.

\section{ABBREVIATIONS}

$P Q$ - Piperaquine

PC - Acetaminophen

AS - Acetylsalicylic acid

$\mathrm{OAC}-\mathrm{CH}_{3} \mathrm{COO}^{-}$

TLC - Thin Layer Chromatography

FTIR - Fourier Transformation Infrared

UV - Ultraviolet

AAS - Atomic Absorption Spectroscopy

IUPAC - International Pure and Applied Chemistry

ACTs - Artemisinin Combination Therapies

IC50s - Concentrations for 50\% parasite growth inhibition

${ }^{1} \mathrm{H}$ NMR - Proton Nuclear Magnetic Resonance

${ }^{13} \mathrm{C}$ NMR - Carbon-13 Nuclear Magnetic Resonance

XRD - X-ray Diffraction

$\mathrm{M}(\mathrm{II})-\mathrm{Cu}^{2+}, \mathrm{Zn}^{2+}, \mathrm{Co}^{2+}$ and $\mathrm{Fe}^{2+}$

\section{REFERENCES}

1. Wiesner J., Ortmann R., Jomaa H., and Schlitzer M., New Antimalarial Drugs, Angew. Chem. Internat. Ed. Engl., 2003, 42 (43), 5274-5293. https://dx.doi.org/10.1002/anie.200200569

2. Maribel N., Techniques used to Study MetalloDrugs-DNA interactions, Ivic Instituto Venezolano De Investigaciones Cientifica, 23-30 Julio, 2010. http://www.riidfcmcyted.fq.edu.uy/archivos/Curso_Tecnicas_aplicadas_al_desarrollo_de_metalofarmacos/presentacione s_clases/hematina.pdf

3. World Health Organisation, Model Formulary for Children (2nd ed.), 2010,ISBN 978-92-4-159932-0. http://www.who.int/entity/selection_medicines/list/WMFc_2010.pdf. Retrieved 2011-03-30

4. World Health Organisation, Model List of Essential Medicines for Children (2 ${ }^{\text {nd }}$ ed.), 2010, http://www.who.int/entity/medicines/publications/essentialmedicines/Updated_second_children_list _en.pdf. Retrieved 2011-03-30.

5. Obaleye J. A., Amolegbe S. A. and Gbotoso G. O., Some metal-antimalarial drug complexes: synthesis, characterization and their effect against malaria http://www.journal.unaab.edu.ng/index.php/COLNAS/article/viewFile/193/190, 2006.

6. Olliaro P. L. and Taylor W. R., Antimalarial compounds: from bench to bedside. J Exp Biol, 2003, 206:3753-3759. DOI: $10.1242 /$ jeb.00653 
Ayipo, Obaleye and Badeggi, JOTCSA. 2017; 4(1): 313-326.

7. Marcus J. R., Rose M., Machteld E. B., Marion B., Stephane P., Mupawjay P., Pratap S. and Francois N., Dihydroartemisinin-Piperaquine Rescue Treatment of Multidrug-resistant Plasmodium Falciparum Malaria in Pregnancy. American Journal of Tropical Medicine and Hygiene, 2008, 78 (4) 543 - 545. https://ora.ox.ac.uk/objects/uuid:e21fb333-b72a-47f1-929d-5cea211bcc0f

8. Sanjukta B. Ranbaxy Laboratory Ltd., India. www.synriam.com/2synriamRanbaxy.pdf, 2013.

9. Ogunniran K. O., Ajani O. O., Ehi-Eromosele C. O., Obaleye J. A., Adekoya J. A. and Ajanaku C. O., $\mathrm{Cu}(\mathrm{II})$ and $\mathrm{Fe}$ (III) complexes of sulphadoxine mixed with pyramethamine: synthesis, characterization, antimicrobial and toxicology study. International Journal of Physical Science, 2012, Vol. 7(13), pp 1998 - 2005. DOI: $10.5897 /$ IJPS11.1143

10. Shruti S. S., Jadhav W. N., Khade B. C. and Arbad B. R., Synthesis, characterization and antimicrobial study of some 3d metal complexes of sulfadoxine. International Journal of ChemTech Research, 2014, Vol. 6, No 4, pp 2291 - 2294. http://sphinxsai.com/2014/vol6pt4/1/(2291-2294)Jul-Aug14.pdf

11. Cotton F. A., Geoffrey W. and Carlos A. M., Advanced Inorganic Chemistry, Wiley, New York, NY, 1988, $6^{\text {th }}$ Ed. ISBN: 978-0-471-19957-1

12. Miessler G. L.; Donald A. T., Inorganic Chemistry, Pearson Education Inc., U. S. A., 1999 , pp. 642. ISBN: 978-0321811059

13. Encyclopedia Britannica, https://en.wikipedia.org/wiki/Encyclopædia_Britannica, 2010.

14. Adediji J. F., Olayinka E. T., Adebayo M. A. and Babatunde O., Antimalarial mixed ligand metal complexes: Synthesis, physicochemical and biological activities. International Journal of Physical Sciences, 2009, 4 (9) 529 - 534.

http://www.academicjournals.org/article/article1380628184_Adediji\%20et\%20al.pdf

15. Lee, J. D., Coincise Inorganic Chemistry; Wiley: India, 1999, pp 223 - 232. ISBN: 978-0-632-052936

16. Karunajeewa H., Lim C., Hung T. Y., Ilett K. F., Denis M. B., Socheat D. and Davis T. M., Safety evaluation of fixed combination piperaquine plus dihydroartemisinin (Artekin) in Cambodian children and adults with malaria. Br J Clin Pharmacol, 2004, 57:93-99. DOI: 10.1128/AAC.00555-07

17. Lawal A. and Obaleye J. A., Synthesis, characterization and antibacterial activity of aspirin and paracetamol-metal complexes. BIOKEMISTRY, 2006, 19 (1): 9-15. http://www.bioline.org.br/bk

18. Jeffery G. H., Basset J., Mendham J., Denney R. C.; Vogel's Textbook of Chemical Analysis, $5^{\text {th }}$ Edition, Wiley \& Sons, Inc., N. Y., pp 339-340. ISBN: 0-582-44693-7

19. Hung T. Y., Davis T. M., Ilett K. F., Karunajeewa H., Hewitt S., Denis M. B., Lim C. and Socheat D.; Population pharmacokinetics of piperaquine in adults and children with uncomplicated falciparum or vivax malaria. Br J Clin Pharmacol, 2004, 57:253262. https://www.ncbi.nlm.nih.gov/pubmed/14998421. 


\section{Piperakin-Asetaminofen ve Piperakin-Asetilsalisilik Asit İçeren Yeni Metal Kompleksleri: Sentez, Karakterizasyon ve Antimikrobiyal}

\section{Aktiviteler}

Ayipo Yusuf Oloruntoyin, Obaleye Joshua Ayoola, Badeggi Umar Muhammad

Öz: Çinko(II), nikel(II), kobalt(II) ve demir(II) komplekseleri, piperakin-asetaminofen ve piperakin-asetilsalisilik asit içeren komplekslerin sentezinde kullanılmıştır. Kompleksler şu yöntemlerle karakterize edilmiştir: Çözünürlük testi, erime noktası tayini, iletkenlik tayini, atomic soğurma spektroskopisi, UV-Görünür spektrofotometri, FTIR spektroskopisi ve manyetik duyarlıık ölçümleri. Komplekslerin her bir metal tuzu ve ligandlar arasında 1:1:1 şeklinde bir stokiyometrik orana sahip olduğu ve tetrahedral ve oktahedral geometrinin tercih edildiği bulunmuştur, kompleksleşme tepkimeleri $M X . \mathrm{yH}_{2} \mathrm{O}+\mathrm{L}_{1} \mathrm{~L}_{2 / 3}$ tepkimesinden $\mathrm{ML}_{1} \mathrm{~L}_{2 / 3} \mathrm{X} . \mathrm{yH} \mathrm{H}_{2} \mathrm{O}$ komplekslerinin oluşması şeklindedir. Sentezlenen komplekslerin biyolojik aktiviteleri Escherichia coli ve Staphylococcus aureus'a karşı değerlendirildi.

Anahtar kelimeler: Antimalaryal aktivite; analjezik bileşikler; karışık ligandlar; spektroskopi; biyolojik aktiviteler.

Sunulma: 05 Ekim 2016. Düzeltme: 17 Kasım 2016. Kabul: 21 Kasım 2016. 
